\title{
Imperial Judicial Policy in the Central Asian Suburbs in the second half of the 19th - early 20th centuries: Main Forms, Directions, and Results
}

\section{Inna V. Anisimova}

Altai State University. Barnaul, Russia. Email: iva0410[at]mail.ru

\section{Abstract}

One of the important directions of modernization of the Central Asian outskirts of the Russian Empire was the formation of the region's judicial system. During the second half of the 19th century, a complex configuration of regional justice was created, which was supposed to act not only as a way of coordinating social interaction but also as a means to express the political interests of the state. The purpose of the work is to identify and analyze the main forms and directions of the judicial policy of the Russian Empire in the Central Asian outskirts in the second half of the 19th - early 20th century. The judicial reform carried out in the Russian Empire in 1864 led to the implementation in the Steppe Region and Turkestan of a set of measures aimed at the re-organization of the judicial and legal system. This process reflected the orientation of the social policy towards modernization. During the reforms of the 1868, 1886, 1898, imperial judicial institutions and legal norms were imported into the region. However, the traditional court also retained significant positions. The justice system of the Central Asian outskirts did not meet the needs of society. The preservation of the People's Court did not allow the local population of the region to be fully incorporated into the all-Russian legal space. Those processes demonstrated the incompleteness of the judicial and legal system reforms and the need for systemic modernization.

The article is intended for specialists interested in the national policy of the Russian Empire, and the history of the Central Asian region.

\section{Keywords}

Russian Empire; Steppe Region; Turkestan; National Policy; Judicial and Legal System; Traditional Law; People's Court; Reforms; Modernization; 19th century

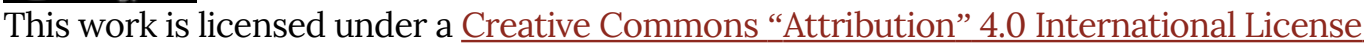




\title{
Имперская судебная политика в Центральноазиатских окраинах во второй половине XIX - начале XX вв.: основные формы, направления и результаты
}

\begin{abstract}
Анисимова Инна Владимировна
Алтайский государственный университет. Барнаул, Россия. Email: iva0410[at]mail.ru

Аннотация

Одним из важных направлений модернизации центральноазиатских окраин Российской империи выступало формирование судебной системы региона, основанной на принципах общеимперской юстиции. На протяжении второй половины XIX в. создавалась сложная конфигурация региональной юстиции, которая должна была не только выступать способом координации социального взаимодействия, но и выражать политические интересы государства. Цель работы заключается в определении и анализе основных форм и направлений судебной политики Российской империи в центральноазиатских окраинах во второй половине XIX начале XX в. Важным является определение степени эффективности проводимых в регионе реформ судебно-правовой системы. Проведение в Российской империи судебной реформы 1864 г. напрямую не затронуло центральноазиатские имперские окраины, но обусловило реализацию в Степном крае и Туркестане комплекса мер, направленных на реорганизацию судебноправовой системы. Данный процесс напрямую отражал модернизационную направленность социальной политики Российской империи. В ходе реформ (1868 г., 1886 г., 1898 г.) в регион частично были импортированы имперские судебные институты и нормы права. Однако значимые позиции сохранял и традиционный суд. При этом неготовность властей к коренному слому традиционного судопроизводства была устойчивой на протяжении всего периода. Сконструированная во второй половине XIX в. система юстиции центральноазиатских окраин не отвечала потребностям общества и характеру правоотношений, была малоэффективной и потенциально конфликтной в результате сочетания традиционных и общеимперских судебных норм и институтов. Сохранение народного суда не позволило в полной мере инкорпорировать местное население региона в общероссийское правовое пространство. Данные процессы свидетельствовали о незавершенности реформ судебно-правовой системы региона и необходимости системной модернизации.
\end{abstract}

Статья предназначена для специалистов, интересующихся вопросами национальной политики Российской империи, историей центральноазиатского региона, а также занимающихся историко-юридическими исследованиями.

\section{Ключевые слова}

Российская империя; Степной край; Туркестан; национальная политика; судебно-правовая система; региональная юстиция; традиционное право; народный суд; реформы; модернизация

Это произведение доступно по дицензии Creative Commons “Attribution” («Атрибуция») 4.0 Всемирная 
Journal of Frontier Studies. 2022. No 1 | ISSN: 2500-0225

Imperial Practices | https://doi.org/10.46539/jfs.v7i1.376

\section{Введение}

Включение в состав Российской империи территорий с иноэтническим и иноязычным населением ставило перед государством проблему распространения имперской правовой и властной системы на созданные административно-территориальные единицы. Завершение присоединения центральноазиатских национальных окраин в середине XIX в. вызвало к жизни необходимость политических, социально-экономических и правовых преобразований в регионе. Именно в этот период отчетливо проявился патерналистский подход в политике России по отношению к народам азиатских окраин, теоретические основы которого нашли практическое воплощение в реализации стратегии их интеграции в политико-правовое и социально-экономическое имперское пространство. Внутренняя политика государства была ориентирована на поиск оптимальной практики управления, обеспечивающей административную, финансово-налоговую, судебно-правовую унификацию его регионов (Лысенко, Анисимова, Тарасова, \& Стурова, 2014, с. 31-40). Содержание национальной политики России, реализуемой в Степном крае, определялось стремлением включить традиционное казахское общество в политикоправовое, социально-экономическое и культурно-языковое пространство. Данный процесс сопровождался трансформацией потестарно-патриархальных отношений и социальных институтов, что было неразрывно связано с модернизацией традиционных обществ колониальных окраин.

Соглашаясь с И.В. Побережниковым, необходимо подчеркнуть, что российская модернизация на протяжении XVIII - начала XX в. осуществлялась в условиях продолжавшегося расширения территории страны, присоединения новых земель и их освоения, что требовало, с одной стороны, максимального разнообразия культурных навыков и этнокультурного взаимодействия и заимствования из культур автохтонных народов. С другой стороны, контакт местного населения с пришлым создавал и для первого предпосылку для совершенствования собственной культуры. Данные процессы в центральноазиатских окраинах носили диффузионный характер; при этом преобладающим был импорт в традиционное общество технологий, социальных институтов, культурных ценностей западного, преимущественно - западноевропейского, происхождения (Побережников, 2013, с. 4-7). В связи с этим особое внимание уделяется судебной системе, которая выступала важным способом координации социального взаимодействия. Путем «мягкой» трансформации традиционных судебных институтов Российская империя стремилась инкорпорировать казахское общество в общегосударственную правовую систему, а также усилить российское присутствие в регионе. 


\section{Источники и методы}

Источниковую базу исследования представляют, прежде всего, архивные документы, отложившиеся в Российском государственном историческом архиве и Центральном государственном архиве Республики Казахстан. Важное значение имеют законодательные источники, представленные основополагающими нормативно-правовыми актами, регламентирующими управление регионом. Отдельную группу источников представляют материалы, опубликованные на страницах официального печатного органа Министерства юстиции «Журнала министерства юстиции», которые выражали позицию ведомства по вопросам становления, развития, характера деятельности судебно-правовой системы региона. В совокупности используемые источники позволяют достичь исследовательской цели.

Исследование опирается на основные положения неоинституциональной теории, которая сегодня активно применяется в историко- правовых исследованиях (Валиев, 2020; Захаров, 2010) «Неоинституционализм» позволяет выделить в судебно-правовой системе центральноазиатских окраин «формальные» (имперские судебные органы) и «неформальные» (суд биев и адат) институты, определить траекторию их развития, проанализировать характер взаимодействия, а также выявить и обосновать эффективность работы судебно-правовой системы региона в целом. В основу исследования также положены принципы концепции фронтирной модернизации, прежде всего, положение о подвижности границы между центром (ядром) и периферией, так как периферийные регионы по мере освоения теряли фронтирные черты и интегрировались в состав ядра (Побережников, 2018). Созданная в центральноазиатских окраинах судебно-правовая система, с одной стороны, была направлена на интеграцию региона в общеимперское пространство, с другой стороны, имея сложносоставной характер и будучи потенциально «конфликтной», определяла специфику модернизационных процессов.

В работе используется проблемно-хронологический принцип, который позволяет выявить и охарактеризовать основные этапы развития судебноправовой системы региона во второй половине XIX в. - начале XX в. Применение системно-структурных методов способствует выделению и анализу элементов исследуемой судебно-правовой системы, установлению особенностей их развития и содержания.

\section{Обсуждение}

Современная историография, имея в своем распоряжении широкий научный инструментарий и источниковую базу, в разной степени проанализировала особенности проводимых в Российской империи реформ государственного и административно-территориального управления, а также судебно-правовой системы. 
Востребованным сегодня является изучение имперских моделей управления в национальных окраинах государства. Можно выделить целый комплекс исследований, посвященный данной тематике (Каппелер, 2010; Любичанковский, 2013; Ремнев \& Суворова, 2013). Под империей в данном случае понимается «способ управления гетерогенным пространством в условиях модернизирующегося общества, способ преодоления мировой локальности» (Любичанковский, 2013, с. 59).

Неоднократно исследователи подчеркивали важную роль имперской юстиции в освоении окраин Российской империи. При этом широкое освещение в современной, как отечественной, так и зарубежной историографии получили вопросы развития традиционных судебных институтов в Степном крае и Туркестане (Почекаев, 2008, 2011; Салиев, 2013а, 2013b). В работах уделяется внимание трансформации норм обычного права, месту и роли в правовой системе суда биев и рассматривается общий ход реформы судебной системы в казахской степи. Значительным вкладом в изучение особенностей национальной политики Российской империи в отношении казахского общества в XIX - начале XX в. стала коллективная монография «Традиционное казахское общество в национальной политике Российской империи: концептуальные основы и механизмы реализации (XIX - начало XX в.)», один из разделов которой посвящен реформам традиционной судебной системы Степного края (Лысенко и др., 2014).

В меньше степени в современной историографии изучены вопросы развития имперской юстиции в центральноазиатских окраинах. Ряд работ посвящен реализации административных и судебных реформ в Туркестанском крае (Васильев, 2014; Нестеренко, 2012; Тухтаметов, 1999). Становление и развитие имперских судебных институтов в Степном крае выступают предметом нашего исследования. В ряде научных публикаций получили освещение работа института мировых судей в регионе, особенности деятельности института крестьянских начальников, становление таких общеимперских институтов как опека, прокурорский надзор, формирование органов социального контроля в регионе (Анисимова, 2018; Анисимова \& Лысенко, 2018).

Однако, несмотря на значительную историографию, изучение особенностей судебно-правовой политики Российской империи в Степном крае не стало предметом комплексного анализа. Уникальность организации региональной юстиции и сложность процесса модернизации судебно-правовых институтов и отношений в центральноазиатских имперских окраинах актуализирует изучение данной проблемы.

\section{Результаты исследования}

На протяжении XIX в. российские имперская администрация планомерно предпринимала шаги по реорганизации судебно-правовой системы казахского 
общества. Уникальность ее реформирования в Степном крае и Туркестанском генерал-губернаторстве заключалась в том, что наряду с формированием общеимперского правового поля власти стремились сохранить и максимально интегрировать в него подвергшиеся модернизации традиционные судебные институты. Данная концепция получила отражение в основных законопроектах XIX в., касающихся изучаемого региона: в «Уставе о сибирских киргизах» 1822 г., «Временном положении об управлении в Степных областях» 1868 г., а также в «Положении об управлении Туркестанским краем» 1886 г. Действительно, в результате реформ, проводимых российской администрацией в Степном крае и Туркестанском генерал-губернаторстве, традиционная структура бийского суда, претерпев существенные изменения, не была полностью исключена из региональной судебной системы. Более того, традиционные судебные институты и правоотношения занимали существенные позиции в региональной юстиции вплоть до 20-х гг. ХХ в.

B первой половине XIX в. имперские власти, не располагая в регионе достаточными ресурсами, не принимали кардинальных мер, направленных на реорганизацию судоустройства казахского общества. Были сформированы общие контуры судебной системы, которая включала в себя пограничную комиссию, окружные приказы (которые приобрели значение уездных судов), военные суды и традиционный суд биев. Функции и компетенции судебных институтов были разграничены, а сама сеть имперских судов была значительно расширена.

Началом нового этапа развития судебно-правовой системы Российской империи стало проведение судебной реформы 1864 г., значение и результаты которой в большинстве случаев оцениваются положительно (Захарова, 1992; Кириллов, 2005; Кодан, 2012; Миронов, 2003). Имперские власти отчетливо осознавали масштабность проводимой реформы, поэтому ее реализацию изначально планировалось растянуть на несколько лет. В опубликованном 19 октября 1865 г. указе Правительствующему Сенату о введении в действие судебных уставов 20 ноября 1864 г. предписывалось: «Уставы сии, в полном их объеме, ввести в течение 1866 г. в округах С.-Петербургской и Московской судебных палат, а в течение четырех лет, начиная с 1866 г. - во всех губерниях» (ПСЗРИ, 1865, с. 75).

Однако в реальности предполагаемые сроки проведения реформы существенно изменились. Распространение Судебных уставов растянулось более чем на 30 лет и завершилось только в 1899 г. Реформа в своем изначальном варианте не получила распространения на ряд российских регионов, в том числе на северные и северо-восточные губернии, Сибирь и Степной край. Согласимся с мнением Е.А. Крестьянникова, что преобразования суда проводились в разных районах Российской империи на неодинаковых началах (Крестьянников, 2009, с. 4). Различные факторы обусловили появление соче- 
таний разнообразных процессуальных обрядов и всевозможных форм судоустройства.

Несмотря на исключение Степного края из сферы распространения Судебных уставов, администрация не могла оставить судебную систему региона в существующем варианте, конфигурация которого не отвечала потребностям развития общества и более не соответствовала характеру правовых отношений. В связи с этим проект реорганизации региональной юстиции был включен в реформу административного управления. В 60-е гг. XIX в. в центральноазиатских окраинах империи произошли серьезные изменения, связанные с образованием новых административно-территориальных единиц (Степных областей и Туркестанского генерал-губернаторства), что повлекло за собой модернизацию региональной системы государственного управления. При этом разработанные и реализованные на окраинах государства механизмы формирования и функционирования имперской администрации обеспечили относительно мирное инкорпорирование нерусских регионов в единое общеимперское пространство (Васильев \& Любичанковский, 2018). В результате принятия в октябре 1868 г. «Временного положения об управлении в Уральской, Тургайской, Акмолинской и Семипалатинской областях» («Временное положение», 2005) произошел импорт в регион некоторых общеимперских институтов судебной власти, а также утверждалось ведение судопроизводства по русским законам. Так, независимо от волостных судов русских переселенцев и станичных судов в казачьих станицах, имперский суд представляли: 1) уездные судьи, учрежденные по одному на каждый уезд, 2) военно-судные комиссии, 3) областные правления и 4) Правительствующий Сенат, который выступал высшей судебной инстанцией в регионе (РГИА, 1898, л. 4). Уездным судьям подсудны были, на правах мировых судей по судебным уставам 20 ноября 1864 г., уголовные дела по проступкам и преступлениям, наказания за которые не связаны с лишением или ограничением прав свободы, а также гражданские дела ценностью до 2000 р. (РГИА, 1897, л. 4) .

При этом, наряду с новыми трансплантированными в регион формальными институтами правовой системы, «Временное положение» сохранило и неформальные институты судебной системы в виде народного суда и традиционных норм права. Значительным успехом «Временного положения» стало внесение в работу традиционной судебной системы казахского общества определенных корректив. В частности, в «Положении» определялась подсудность казахов как общеимперской судебной системе, так и народному суду.

Изменения касались также статуса народного судьи. Согласно «Положению», должность биев приобрела выборный характер с обязательным утверждением кандидатуры губернатором. Утверждалась трехуровневая структура народного суда: бийский суд и волостные съезды биев, распределение дел между которыми зависело от исковой суммы, а также чрезвычайные съезды, созываемые уездными начальниками. В целом «Временное положение» 1868 г. 
стало важным этапом в модернизации системы юстиции Степного края. Однако сочетание в судоустройстве формальных и неформальных институтов делали саму систему потенциально конфликтной.

Вскоре недостатки существующей конфигурации судебной системы стали очевидны как региональным властям, так и высшим правительственным структурам Российской империи. Чиновники стали говорить о малоэффективности и низкой результативности работы каждого из формальных институтов судебной системы. Критике подверглись работа в качестве судебной инстанции Областного правления (сочетание в одних руках административных и судебных функций), кадровая проблема (нехватка юристов, незнание чиновниками судебного ведомства языка коренного населения, отсутствие образовательного ценза для работников судебных институтов), распространение функций мирового института на уездных судей. Причины низкой эффективности работы судебных институтов виделись чиновникам министерства юстиции в размерах судебных участков и отсутствии транспортных коммуникаций. Так, чиновники министерства юстиции в одном из отношений, направленных министру внутренних дел, подчеркивали, что

«при громадном протяжении большинства уездов Туркестанского края и Степных областей, были до крайности обременены <..> уездные судьи, в ведение коих сосредоточена была судебная и следственная власть, вследствие чего у многих из этих должностных лиц накопилось уже вскоре по 1000, 1500 и более неоконченных дел обеих категорий» (РГИА, 1897, лл. 5-5 об.).

Широкому обсуждению подверглось и сохранение неформальных институтов в судебной системе. Региональные чиновники нередко заявляли о необходимости поглощения имперским судом суда бийского и распространения на казахское население общеимперских норм права. Подобной позиции придерживался туркестанский генерал-губернатор К.П. Кауфман, который, проанализировав характер судебной системы, утвержденной Временным положением, и опыт его реализации в Туркестане и Степных областях счел необходимым для придания суду региона более высокого статуса в глазах населения и роста его эффективности расширить границы подсудности русскому суду, придать русскому суду статус общего суда в крае «не в отношении только порядка производства дел, т.е. официальной стороны судоустройства и судопроизводства, но и внутренней ее стороны - разрешения самой сущности дела, применением норм русского права», предоставить местному населению свободный доступ к имперскому суду. При этом Кауфман не настаивал на ликвидации институтов традиционного судопроизводства; народный суд

«должен остаться только как исключение из суда общего, допускаемое в определенных делах между туземцами одинаковой народности, если обе стороны согласны на этот исключительный порядок суда, и ни одна из них не заявит желания судится в суде общем» (РГИА, 1871, лл. 144-167). 
Для изучения ситуации в регионе в 1882 г. в Туркестанском крае была назначена ревизия Ф.К. Гирса. Результаты ревизии были рассмотрены особой комиссией под руководством графа Игнатьева, решение которой легко в основу нового законодательного акта. Практически через 20 лет действия «Временного положения» после многочисленных дискуссий и длительного обсуждения начался новый этап реформы судебно-правовой системы региона. В 1886 г. было принято и введено в действие «Положение об управлении Туркестанского края» («Положение», 1886). «Положение» получило распространение и на Степной край. С 1 января 1887 г. полномочия уездных судей были переданы мировым судьям, а судебные функции судных отделений областных правлений и канцелярии туркестанского генерал-губернатора - областным судам (Лысенко и др., 2014, с. 161-163). Нивелировав наиболее спорные проблемы в деятельности формальных институтов, «Положение об управлении Туркестанским краем» сохранило и институционализировало работу народного суда. При сокращении компетенций народного суда (из введения последнего были изъяты преступления против государственной власти, правонарушения, связанные с нанесением вреда государственному имуществу) правовые возможности традиционного судебного института были расширены. Суд биев по-прежнему регламентировал весь комплекс семейно-брачных отношений, обращение в имперский суд было возможным только при обоюдном согласии участников судебного процесса и т.д. «Положение» определило «независимость» народного суда от государственной системы, так как отказалось от материального обеспечения деятельности биев. Определение размера вознаграждения последних за работу производилось самими судьями «по обычаю». Конечно, последнее усиливало бесконтрольность народного суда региональной администрации, так как в данном случае привлечь судью за должностное правонарушение или взяточничество было практически невозможно.

В результате проведенной реорганизации к концу XIX в. судебно-правовая система Степных областей сочетала в себе институты традиционного суда, полномочия которых по «Положению» 1886 г. были расширены и закреплены, а также общеимперскую дореформенную систему судов. На регион по-прежнему не получили распространение Судебные уставы 1864 г., что в целом не отвечало политике интеграции региона в общеимперское пространство и модернизации системы государственного управления.

Почти одновременно с вопросом о преобразовании управления Туркестанского края было признано необходимым принять меры к улучшению управления Степными областями. В 1883 г. Государственный Совет, рассмотрев представление Министерства Государственных Имуществ об учреждении управления государственными имуществами в Западной Сибири, указал на то, что существовавший в Степных областях порядок управления «крайне ненор- 
мален», и что необходимо приложить максимальные усилия правительства для его изменения.

Министрам внутренних дел, финансов, юстиции, государственных имуществ и военному было предложено в ближайшее время разработать и внести на рассмотрение Государственного совета проект устройства административных учреждений и судебной части в Уральской, Тургайской, Акмолинской, Семиреченской и Семипалатинской областях. Для разработки нового проекта при Министерстве внутренних дел была образована специальная комиссия под руководством статс-секретаря В.К. Плеве. Выработанные комиссией предложения были представлены в Государственный совет в мае 1890 г., а 25 марта 1891 г. получило утверждение «Степное положение». Однако новый законодательный акт не внес в судоустройство региона кардинальных изменений, направленных на усовершенствование сложившейся модели.

В связи с этим на протяжении 90-х гг. XIX в. в правительственных кругах активно обсуждался характер проведенных в Степном крае и Туркестане реформ, говорилось о неэффективности судебной системы и несоответствии региональной юстиции общественным потребностям (ЦГА РК, 1897, л. 52 об.; Черданцев, 1899, с. 116).

В 1894 г. министерство юстиции вновь инициировало рассмотрение вопроса о преобразовании судебной части в Туркестанском крае и Степных областях. Императором Александром III было принято решение о создании особой комиссии под председательством министра юстиции Н.В. Муравьева с напутствием:

«твердо уверен в необходимости всестороннего пересмотра наших судебных уставов, чтобы наконец действительное правосудие царило в России. И так с божьей помощью начинайте эту трудную работу» (РГИА, 1904, л. 4).

Конечно, речь шла, в том числе, о необходимости распространения в полной мере на центральноазиатские окраины Российской империи Судебных уставов 1864 г. Параллельно с этим вопросом в правительстве шло обсуждение судебной реформы в Сибири, где Уставы также не получили распространения.

Обосновывая необходимость реформы судебной системы, империи министр Муравьев подчеркивал, что

«значительно отошли от первоначального типа нового суда постановления о применении его к окраинам, отличавшихся чрезвычайным и чрезмерным разнообразием. Замедлилось и территориальное расширение судебной реформы, встречавшее различные препятствия и отодвинутое на десятки лет вместо того, чтобы завершится, как сначало предполагалось, вскоре по издании судебных уставов» (РГИА, 1904, л. 18).

В заключении работы Комиссии по пересмотру законоположений Муравьев писал: 
«К началу девятидесятых годов минувшаго столетия положение реформированной юстиции отнюдь не могло считаться упрочненным и ясным; ее окружала смутная атмосфера колебания и шаткости...» (РГИА, 1904, лл. 19-20).

В связи с этим особое звучание приобрела проблема модернизации судебной системы центральноазиатских окраин. Подчеркнем, что необходимость преобразований сложившейся к концу XIX в. системы народного судопроизводства в казахском обществе была очевидна для всех уровней власти. Чиновниками предлагалось либо ограничить возможности народного суда частично, либо полностью инкорпорировать его в общеимперскую правовую систему.

В частности, о важности и необходимости полного включения «инородцев» в общеимперское судебно-правовое пространство говорили министр внутренних дел И.Л. Горемыкин и министр Императорского двора и уделов И.И. Воронцов-Дашков. В заключениях руководителей двух крупнейших ведомств рассматривалась возможность распространения на казахов раздела об организации судебной части «Общего Положения о крестьянах, вышедших из крепостной зависимости», принятого 19 февраля 1861 г. Министры предлагали сохранить у казахов бийский суд, но существенно уменьшить его компетенции и превратить в низовую судебную инстанцию, по подобию волостного суда у крестьян российских губерний.

В это же время Государственный Совет, соглашаясь в целом с необходимостью реформ народного суда в регионе, подчеркивал, что

\begin{abstract}
«не следует упускать из вида, что, по своим представлениям о праве и справедливости, туземцы и инородцы нередко вполне еще расходятся с русскими законами. Поэтому слишком поспешное привитие им этих законов могло бы породить смуту в их умах и в сложившемся изстари строе их жизни. В виде сего, пока, придется, может быть, держаться по обсуждаемому вопросу несколько иного пути, а именно постепенного улучшения народного суда» (РГИА, 1898, л. 228).
\end{abstract}

Тем не менее, в ходе длительного обсуждения ведомства сумели прийти к единому решению о проведении реформы судебной части в Степном крае и распространении на его территории Судебных уставов 1864 г. 14 марта 1898 г. Государственный Совет принял решение предоставить на утверждение императора Александра III проект «Временных правил о применении судебных уставов к областям Сыр-Дарьинской, Самаркандской, Ферганской, Семиреченской, Акмолинской, Семипалатинской, Уральской и Тургайской» (РГИА, 1898, лл. 221-234).

Итак, судебная реформа 1898 г. стала завершающим этапом вхождения Туркестанского края и Степных областей в общеимперское правовое пространство. В результате принятия закона от 2 июля 1898 г. «О преобразовании судебной части в Туркестане и Степной области» региональная юстиции была реорганизована в соответствие с Судебными уставами 1864 г. На Степной 
край получили распространение пореформенные судебные институты и общеимперские нормы права. В 1899 г. были открыты Омская и Ташкентская судебные палаты, в подчинение которых вошли имперские суды Степного края и Туркестана. Тогда же состоялось открытие Уральского, Омского, Семипалатинского, Ташкентского, Ново-Маргеланского, Верненского и Асхабадского окружных судов («Всеподданейший доклад», 1899, с. 117-118). Распространение получил и институт мировых судей. Однако большинство вопросов, требующих рассмотрения, так и осталось за рамками преобразований. Прежде всего, реформа при, в целом, модернизационном характере сохранила неформальные судебно-правовые институты региона: суд биев и нормы адата. Нерешенность вопроса, который вызывал наибольшие споры и критику, делала судебно-правовую систему нерациональной, конфликтной и существенно снижала общую эффективность проводимой реформы.

В первые десятилетия XX в. среди прогрессивной части представителей имперской власти вновь актуализировалось обсуждение характера судебной системы центральноазиатских окраин. В июне 1904 г. для обсуждения законопроектов по пересмотру законоположений об организации судебной части в Российской империи в составе Государственного совета было учреждено Особое совещание под руководством действительного тайного советника И.Л. Горемыкина (РГИА, 1904). Совещание, в частности, рассматривало результаты работы Особой комиссии по председательством министра юстиции Н.В. Муравьева, созданной в 1894 г. и предшествовавшей проведению реформы 1898 г. Однако уже в 1905 г. все материалы без решения были возвращены в Министерство юстиции (Терентьев, 2001, с. 142).

Важное влияние на изучение характера судебно-правовых отношений в Туркестане и Степном крае оказали результаты ревизии сенатора Палена, проведенной в 1908-1910 гг. (Отчет, 1909). Ход, содержание и итоги ревизии К.К. Палена сегодня получили достаточное освещение в историографии (Васильев, 2018; Махмудова, 2016). Подчеркнем, что проведение ревизии Туркестанского края было вызвано необходимостью пересмотра Положения об управлении Туркестанским краем, в том числе реорганизации судебной системы региона. Критике сенатора подверглись практически все судебные институты, как имперские, так и традиционные. Граф Пален придерживался четкой позиции относительно архаичности народного суда и необходимости его реорганизации.

«В господстве мертвых, по своей неподвижности, и неясных правил мусульманского права и первобытных подчас жестоких норм киргизского обычая, кроется едва ли не главнейшее основание неудовлетворительности решений туземных судов по гражданским делам <...> (РГИА, 1910, лл. 2-8).

К.К. Пален настаивал на проведении кардинальной реформы народного суда, подчеркивая, что государство, создавая более совершенные формы суда, гарантирующие его справедливость и беспристрастие, «способствует повы- 
шению в населении правовых понятий» (Отчет, 1909, с. 203-205). Выводы К.К. Палена о характере судоустройства Туркестана и Степного края вызвали широкое обсуждение, но не послужили основанием для проведения реорганизации судебной системы региона.

О том, что предпринимаемые шаги по модернизации судебной системы региона носили непоследовательный характер и в их проведении отсутствовал комплексный подход, свидетельствует один из многочисленных случаев. В январе 1911 г. прокурор Омской судебной палаты обратился к министру юстиции по вопросу об увеличении числа мировых судей в Акмолинской области. Прокурор подчеркивал, что 13 мировых судей Акмолинской области не справляются с количеством возникающих дел мировой подсудности и предварительных следствий, увеличение которых вызвано в том числе и наплывом переселенцев в область. Так, Атбасарский уезд при территории в 118,6 кв. верст и населением в 133 тыс. чел. составляет один мировой участок и обслуживается одним мировым судьей, на котором лежит разбор всех дел и вся следственная часть. Кокчетавский уезд с населением в 261 тыс. чел. обслуживается в судебном отношении двумя мировыми судьями. Прокурор в своем обращении отмечал, что при проектировании расширения штата судей в Атбасарском и Кокчетавском уездах увеличения судей не предусматривалось. При этом, по мнению прокурора, «сложность обязанностей, поразительный рост дел, <...> пространственное протяжение мировых участков» делали необходимым увеличение числа судей» (РГИА, 1911, лл. 1-1 об.). Безусловно, в сложившихся условиях нельзя было говорить о результативности работы судебных институтов.

В 1913 г. министром внутренних дел Н.А. Маклаковым были разработаны предложения о пересмотре разделов Степного положения, регламентировавших общественное управление и судебное устройство казахов. Для обсуждения этого проекта было созвано Особое Совещание во главе с товарищем министра Внутренних дел тайного советника Лыкошина, в котором приняли участие чиновники различных ведомств, в том числе и министерства юстиции. По мнению министра внутренних дел, одним и наиболее существенных вопросов, требующих обсуждения, «является вопрос об устройстве судебной части в киргизских степях, в виду совершенной непригодности для целей правосудия института народного суда» (РГИА, 1913, л. 1).

При этом позиция главы МВД отличалась, в определенном смысле, двойственностью. В своем обращении к министру юстиции И.Г. Щегловитову Маклаков, подчеркивая необходимости реформы судебной системы региона, в то же время отмечал, что не решается

«на полную замену народного суда коронным, как потому, что при таком разрешении настоящего вопроса в степных областях могло бы создаться резкое различие в устройстве низших степеней суда, так и в виду тех осложнений, какие могли бы возникнуть для коронного суда при рассмотрении дел между 
крестьянским и инородческим населением, одинаково принадлежащим к составу сельских обывателей, но подчиненным различным по существу, судебным установлениям» (РГИА, 1913, лл. 1-1об.).

В связи с этим министр внутренних дел предлагал в качестве возможного варианта не упразднять народный суд, а провести его преобразование в соответствие с общественными реалиями. В частности, речь шла о возможном подчинении народного суда надзору крестьянских учреждений, об образовании участковых съездов судей под председательством крестьянского начальника и о присвоении уездному съезду обязанностей третьей кассационной инстанции. Предусматривалось расширение обязанностей мировых судей за счет обеспечения надзора за волостным инородческий судом и председательства в участковых съездах. Проект реформ получил поддержку со стороны министерства юстиции. В результате работы межведомственной комиссии был выработан проект Положения об общественном устройстве и управлении оседлых и кочевых инородцев Акмолинской, Семипалатинской, Уральской и Тургайской областей, который был согласован с Степным генерал-губернатором и губернаторами Уральской и Тургайской областей.

Основные положения преобразований суда кочевого населения сводились к созданию в инородческих волостях волостного судебного участка и открытия инородческого волостного суда (по аналогии с идеей, высказанной в свое время министром внутренних дел И.Л. Горемыкиным и министром Императорского двора и уделов И.И. Воронцовым-Дашковым). По проекту, инородческий волостной суд мог рассматривать все без ограничения суммы споры и тяжбы между казахами, если истец и ответчик желают судиться в этом суде. При желании стороны могут судиться у Крестьянского или инородческого начальника, мирового судьи или в окружном суде. Инородческий волостной суд мог рассматривать и уголовные дела, которые «совершены в пределах волости инородцами против лиц того же состояния и без участия лиц других состояний, а также когда означенные проступки и нарушения не находятся в связи с уголовными преступлениями, подлежащими рассмотрению общих судебных мест». Из компетенции инородческого суда исключались дела о конокрадстве и краже домашнего скота.

В 1913 г. чиновники министерства юстиции после обсуждения положения народного суда в Степных областях пришли к заключению, что действующий народный суд не отвечал «целям правосудия», в связи с чем насущным было проведение кардинальной реформы по его окончательному упразднению и внедрению в полной мере институтов общеимперской юстиции. В тоже время, как подчеркивалось в объяснительной записке Проекта, осуществлению реформы препятствовали объективные обстоятельства. В частности,

«введение института выборных мировых судей, в виду кочевого состояния населения составляющего при том же в общей массе подавляющее большинство (в Семипалитнской области 85\%, в Акмолинской области 50\%, Тургайской 60\%, 
Уральской 80\%), значительно уступающего русскому населению в культурном отношении, и в массе своей неграмотного не только по-русски, но и по-киргизски, представляется совершенно неосуществимым. Затем передача всех дел подведомственных ныне народному суду, мировым судьям по назначению от правительства представила бы также весьма существенные затруднения как в смысле финансовом, так еще более в смысле возможности подыскать соответствующий для сего контингент лиц, способных не только разобраться со всею массой мелких, повседневных дел, но и с тем обычным правопорядком и хозяйственно-общественным укладом, который не может не приниматься в соображение судьей при рассмотрении поступающих к нему дел» (РГИА, 1913, л. 119 об. - 120).

Таким образом, отсутствие достаточных финансовых возможностей, а также кадровых ресурсов, не только имеющих необходимое юридическое образование, но и знающих язык и правовые нормы казахского населения, не позволяют

«поднимать вопроса о полном упразднении народного суда, а ограничиться лишь принятием в отношении его таких мер, которые устраняли бы главнейшие его недостатки и тем способствовали бы лучшей постановке правосудия в инородческой среде» (РГИА, 1913, л. 120).

К аналогичному выводу о роли и месте народного суда в судебной системе региона пришло Совещание под председательством Государственного контролера статс-секретаря Харитонова, занимавшееся в 1911 г. выработкой основных начал для преобразования управления Туркестанским краем. Однако заключение Харитонова в свою очередь подверглось критике и коррекции со стороны Совета министров, который настаивал на совершенном упразднении народных судов в Туркестанском крае и передаче подведомственных им дел органам мировой юстиции. Позиция Совета министров была обусловлена усилением влияния ислама среди населения региона и более широкого распространения в судебной практике норм шариата с постепенным вытеснением адата. Однако, по мнению министерства юстиции, для Степных областей усиление исламизации населения было не характерно. Сдерживающим фактором данного процесса выступало широкое развитие переселения славянского населения в Степные области, что стимулировало процессы аккультурации, заимствовования кочевым населением элементов хозяйственного и бытового уклада, обычаев и социальных практик переселенцев. В связи с этим сохранение в судебной системе традиционного суда не представляло опасности для «государственных интересов».

В качестве аргумента для сохранения народного суда приводился закон от 15 июня 1912 г. о местном суде (Верняев, 2018; Закон, 1912). Чиновники министерства юстиции подчеркивали:

«Если по закону 15 июня 1912 г. <...> признано необходимым сохранить временно для сельского населения волостной суд, то едва ли было бы правильным лишать киргизское население, без достаточных к тому оснований, права на такой же 
суд, особенно, когда полная замена его судом мировой юстиции представляется пока неосуществимой. Уравнивая, поэтому киргизов в этом отношении с русским населением, надлежало бы, сохранив у них временный народный суд, внести в его организацию и строй такие улучшения, которые <...> способствовали бы постановке дела правосудия в киргизской среде» (РГИА, 1913, лл. 121-121 об.).

Данная позиция завершила на некоторое время обсуждение вопроса о модернизации судебно-правовой системы Степного края и сохранила ее конфигурацию без изменений. Элементы традиционного судопроизводства сохранили свои позиции в региональной юстиции, что было обусловлено несогласованностью работы имперских органов власти и отсутствием единой позиции по поводу содержания модернизации социальной системы традиционного общества центральноазиатских окраин.

\section{Выводы}

На протяжении второй половины XIX в. Российская империя стремилась к выработке оптимальной управленческой модели, способствующей как унификации всех территорий государства, так и интеграции национальных окраин в общеимперское пространство. Особое место в связи с этим занимает судебно-правовая система. Создание единого имперского правового поля могло свидетельствовать об эффективности как судебной власти, так и государственного управления в целом. Однако различный уровень социокультурного, экономического и политического развития национальных окраин, геополитические интересы метрополии в колониях привели к формированию региональной вариативности имперского судоустройства. Для центральноазиатских окраин специфика судебно-правовой системы выражалась в сочетании традиционных институтов и норм права, дореформенных общеимперских судебных институтов, введении в действие Судебных Уставов 1864 г. только в 1898 г. Сложная конфигурация судебной системы неоднократно выступала предметом активного обсуждения как региональными, так и центральными органами власти. Нередко результатом подобных дискуссий было принятие частичных мер, направленных на модернизацию институтов юстиции. Однако идея реформы судоустройства региона имперскими властями так и не была реализована.

Амбивалентное отношение государственной власти к судебно-правовой системе Степных областей обусловливалось как политическими факторами, так и «неготовностью» населения центральноазиатских окраин принять институты и ценности европейской культуры. Конструкция судебной системы Степного края и Туркестана второй половины XIX - начала XX вв. не отвечала общественным потребностям и характеру правоотношений, отчасти препятствовала развитию социальных коммуникаций. Проблемы в развитии судебных институтов региона существенно снижали результативность модернизационных 
процессов в центральноазиатских окраинах Российской империи, отражая в то же время специфику региональной национальной политики.

\section{Благодарности}

Статья подготовлена в рамках гранта Президента РФ для государственной поддержки ведущих научных школ Российской Федерации (НШ-2693.2020.6 «Государственное регулирование социальных процессов в Центрально-Азиатском регионе России имперского и советского периодов»).

\section{Список литературы}

Анисимова, И. В. (2018). Формирование и развитие системы социального контроля в Степном крае во второй половине XIX - начале XX вв. Былые годы, 48(2).

https://doi.org/10.13187/bg.2018.2.618

Анисимова, И. В., \& Лысенко, Ю. А. (2018). Особенности организации и деятельности института мировых судей в Степном крае в конце XIX - начале XX в. Известия Алтайского государственного университета, 2(100), 15. https://doi.org/10.14258/izvasu(2018)2-01

Валиев, Р. Г. (2020). Правовая институционализация и институты права: Концептуальная модель. Lex Russica, 4, 103-116. https://doi.org/10.17803/1729-5920.2020.161.4.103-116

Васильев, Д. В. (2014). Организация управления в Русском Туркестане по проектам Положения об управлении 1870-х гг. Интернет-журнал «НАУКОВЕДЕНИЕ», 5, 1-23.

Васильев, Д. В. (2018). Классический пример ориентализма. Мемуары К. К. Палена как взгляд высокопоставленного чиновника на миссию России в Туркестанском крае. Вестник Оренбургского государственного педагогического университета, 28, 87-100. https://doi.org/10.32516/2303-9922.2018.28.8

Васильев, Д. В., \& Любичанковский, С. В. (2018). Административная аккультурация коренного населения Туркестанской области в российском законодательстве 1865-1866 годов. Вестник Волгоградского государственного университета. Серия 4. История. Регионоведение. Международные отношения, 6, 61-75. https://doi.org/10.15688/jvolsu4.2018.6.4

Верняев, И. И. (2018). Реформа местного суда 1912 г. В имперском измерении: Как строить общие институты в многосоставном обществе. Новейшая история России, 8(4).

https://doi.org/10.21638/11701/spbu24.2018.412

Временное положение об управлении в Уральской, Тургайской, Акмолинской и Семипалатинской областях (21 октября 1868 г.). (2005). В Древний мир права казахов (материалы, документы и исследования в десяти томах) (Т. 5, сс. 441-463). Жеті жарғы.

Всеподданнейший доклад министра юстиции о ходе работ по улучшению судебной части за 1894-1899 г. (1899). Журнал Министерства юстищии, 7, 117-118.

Закон 15 июня 1912 г. О преобразовании местного суда. (1912). Сенатская типография.

Захаров, В. В. (2010). Неоинституционализм в историко-правовых исследованиях: К проблеме расширения методологического инстументария отечественной истории государства и права. Ученые записки. Электронный научный журнал Курского государственного университета, 3, 36-44. 
Захарова, Л. Г. (1992). Самодержавие и реформы в России. 1861-1874. (К вопросу о выборе пути развития). В Великие реформы в России, 1855-1874 (сс. 24-43). Издательство МГУ.

Каппелер, А. (2010). «Россия - Многонациональная империя»: Некоторые размышления восемь лет спустя после публикации книги. В Мифы и заблуждения в изучении илперии и национализма (сс. 265-282). Новое издательство.

Кириллов, В. В. (2005). История реформ и контрреформ в контексте российской модернизации XVIII-XX веков. Московский городской педагогический университет.

Кодан, С. В. (2012). Политико-юридический подход в исследовании государственно-правового развития России (XIX - начало XX в.). NB: Проблемы общества и политики, 2, 88-117. https://doi.org/10.7256/2306-0158.2012.2.177

Крестьянников, Е. А. (2009). Судебная реформа 1864 г. В Западной Сибири. Издательско-полиграфический Центр «Экспресс».

Лысенко, Ю. А., Анисимова, И. В., Тарасова, Е. В., \& Стурова, М. В. (2014). Традиционное казахское общество в национальной политике Российской илперии: Конщептуальные основы $u$ механизмы реализации (XIX - начало XX в.). Азбука.

Любичанковский, С. В. (2013). Империя Романовых и проблема управления культурно-гетерогенным пространством. Уральский исторический вестник, 3, 59-68.

Махмудова, Н. Б. (2016). Сенаторская ревизия графа К.К. Палена в Туркестане: Причины, ход, последствия. Метаморфозы истории, 7, 134-150.

Миронов, Б. (2003). Социальная история России периода илперии (XVIII - начало XX в.). Генезис личности, демократической семьи, грањданского общества и правового государства: В 2 mомах (Т. 2). Дмитрий Буланин.

Нестеренко, Л. С. (2012). Распространение судебной реформы 1864 г. В Туркестанском крае. В Социально-гуманитарные и юридические науки: Современные тренды в изменяющемся мире. Премьер.

Отчет по ревизии Туркестанского края, произведённой по Высочайшему повелению Сенатором Гофмейстером Граф ом К.К. Паленом. Народные суды Туркестанского края. (1909). б. и.

Побережников, И. В. (2013). Фронтирная модернизация в российском цивилизационном контексте. Региональные аспекты цивилизационного развития российского общества в ХХ столетии: Проблемы индустриализащии и урбанизащии. Материалы межрегиональной научной конференции. 6-7 июня 2013 г., 3-10.

Побережников, И. В. (2018). Фронтирная модернизация на востоке Российской империи: Региональные вариации. Уральский исторический вестник, 61(4), 72-80. https://doi.org/10.30759/1728-9718-2018-4(61)-72-80

Полное собрание законов Российской илперии. Собрание Второе. 1825-1881 г2. (В 55 томах + тома дополнений и указателей) (Т. 40). (1865). Типография II Отделения Собственной Его Императорского Величества Канцелярии.

Положение об управлении Туркестанского края 1886 г. (1886). Хронос. http://www.hrono.ru/dokum/turkestan1892.html

Почекаев, Р. Ю. (2008). Основные этапы эволюции казахского суда биев (XV-начало XX вв.). Зангер, 4, 51-58. 
Почекаев, Р. Ю. (2011). Правовая ситуация в Казахстане в составе Российской империи. Ч. 3: Право и суд Казахстана в составе Российской империи (1868-1917 гг.). Вопросы истории u археологии Западного Казахстана, 1, 57-75.

Ремнев, А. В., \& Суворова, Н. Г. (2013). Колонизащия Азиатской России: Илперские и нащиональные сценарии второй половины XIX-начала XX века. Наука.

Российский государственный исторический архив (РГИА). (1871). Ф. 1405. Оп. 69. Д. 7108 - a.

Российский государственный исторический архив (РГИА). (1897). Ф. 1291. On. 84. № 18-1897.

Российский государственный исторический архив (РГИА). (1898). Ф. 565. Оп. 7. Д. 29084.

Российский государственный исторический архив (РГИА). (1904). Ф. 1587. Оn. 1. Д. 1.

Российский государственный исторический архив (РГИА). (1910). Ф. 1396. Оп. 1. Д. 441.

Российский государственный исторический архив (РГИА). (1911). Ф. 1405. On. 532. Д. 2.

Российский государственный исторический архив (РГИА). (1913). Ф. 1405. On. 532. Д. 491.

Салиев, А. Л. (2013а). О попытках царской власти сблизить судопроизводство кочевого населения Туркестана с общероссийскими судом и законодательством (по архивным, правовым и иным материалам). Вестник Кыргызско-российского славянского универсиmema, 13(12), 77-80.

Салиев, А. Л. (2013b). Царская власть и народные суды кочевого населения Туркестана: Проблемы взаимоотношений (по архивным, правовым и иным материалам). Вестник Кыргызско-российского славянского университета, 13(6), 41-43.

Терентьев, Р. В. (2001). Правительственные законопроекты по реформированию местного судопроизводства в России в конце XIX - начале XX веков. Ученые записки Санкт-Петербургского илени В.Б. Бобкова филиала Российской таможенной академии, 4, 140-146.

Тухтаметов, Ф. Т. (1999). Правовое положение Туркестана в Российской империи: (Вторая половина XIX века). Башкирский государственный университет.

Центральный государственный архив Республики Казахстан (ЦГА РК). (1897). Ф. 64. On. 1. Д. 767.

Черданцев, Н. С. (1899). О некоторых ненормальностях в устройстве народного суда в Туркестанском и Степном генерал-губернаторствах. Журнал Министерства юстищии, 2.

\section{References}

Act of 15 June 1912. On the transformation of the local court. (1912). Senate printing house. (In Russian).

Anisimova, I. V. (2018). Formation and Development of the Social Control System in the Steppe Krai in the second half of the 19th - early 20th century. Bylye Gody, 48(2).

https://doi.org/10.13187/bg.2018.2.618 (In Russian).

Anisimova, I. V., \& Lysenko, Y. A. (2018).Special Aspects of the Organization and the Activity of the Institute of Justices of the Peace in the Steppe Region at the End of the 19th - the Beginning of the 20th Centuries. Izvestia of Altai State University, 2(100), 15. https://doi.org/10.14258/izvasu(2018)2-01(In Russian).

Central State Archive of the Republic of Kazakhstan. (1897). F. 64. In. 1. C. 767. (In Russian). 
Cherdantsev, N. S. (1899). On some abnormalities in the organization of the people's court in the Turkestan and Stepnoy Governorates-General. Journal of the Ministry of Justice, 2. (In Russian).

Complete Collection of Laws of the Russian Empire. Collection Two. 1825-1881. (In 55 volumes + volumes of supplements and indexes) (Vol. 40). (1865). Printing Office II of His Imperial Majesty's Own Chancellery. (In Russian).

Comprehensive report of the Minister of Justice on the progress made in improving the judicial system in 1894-1899. (1899). Journal of the Ministry of Justice, 7, 117-118. (In Russian).

Kappeler, A. (2010). "Russia - A Multinational Empire": Some Reflections Eight Years After the Book's Publication. In Myths and misconceptions in the study of empire and nationalism (pp. 265-282). New publisher. (In Russian).

Kirillov, V. V. (2005). History of reforms and counter-reforms in the context of Russian modernization in the 18th and 20th centuries. Moscow City Pedagogical University. (In Russian).

Kodan, S. V. (2012). Political-legal approach in the study of state-legal development of Russia (19th early 20th century).. NB: Societal and political issues, 2, 88-117. https://doi.org/10.7256/23060158.2012.2.177 (In Russian).

Krestyannikov, E. A. (2009). The judicial reform of 1864 in Western Siberia. Publishing and Printing Centre "Express". (In Russian).

Lubichankovsky, S. V. (2013). The Romanov Empire and the Problem of Cultural Heterogeneity Management. Ural Historical Herald, 3, 59-68. (In Russian).

Lysenko, Y. A., Anisimova, I. V., Tarasova, E. V., \& Sturova, M. V. (2014). Traditional Kazakh Society in the National Policy of the Russian Empire: Conceptual Foundations and Mechanisms of Implementation (19th - beginning of the 20th century). Azbuka. (In Russian).

Makhmudova, N. B. (2016). The Senatorial Revision of Count K.K. Palen in Turkestan: Reasons, Course and Consequences. The metamorphosis of history, 7, 134-150. (In Russian).

Mironov, B. (2003). Social History of Russia in the Imperial Period (18th - early 20th centuries). The Genesis of the Individual, the Democratic Family, Civil Society and the Rule of Law: In 2 Volumes (Vol. 2). Dmitry Bulanin. (In Russian).

Nesterenko, L. S. (2012). Dissemination of the Judicial Reform of 1864 in the Turkestan Region. In Humanities and Social Sciences and Law: Current Trends in a Changing World. Premier. (In Russian).

Poberezhnikov, I. V. (2013). Frontier modernisation in the Russian civilisational context. Regional Aspects of Civilizational Development of Russian Society in the 20th Century: Problems of Industrialization and Urbanization. Proceedings of the Interregional Scientific Conference. 6-7 June 2013., 3-10. (In Russian).

Poberezhnikov, I. V. (2018). Frontier Modernization in the East of the Russian Empire: Regional Variations. Ural Historical Herald, 61(4), 72-80. https://doi.org/10.30759/1728-9718-2018-4(61)-72-

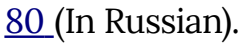

Pochekaev, R. Yu. (2008). The main stages in the evolution of the Kazakh Bishops' Court (15th - early 20th centuries). Zanger, 4, 51-58. (In Russian).

Pochekaev, R. Yu. (2011). The legal situation in Kazakhstan as part of the Russian Empire. Ч. 3: Law and Courts in Kazakhstan within the Russian Empire (1868-1917). Issues of History and Archaeology of Western Kazakhstan, 1, 57-75. (In Russian). 
Provisional Regulation on Governance in the Urals, Turgai, Akmola and Semipalatinsk Regions (21 October 1868). (2005). In The Ancient World of Kazakh Law (materials, documents and research in ten volumes) (Vol. 5, pp. 441-463). Zheti Zharghy. (In Russian).

Regulations on the Management of Turkestan Territory, 1886. (1886). Chronos. http://www.hrono.ru/dokum/turkestan1892.html (In Russian).

Remnev, A. V., \& Suvorova, N. G. (2013). Colonisation of Asiatic Russia: Imperial and National Scenarios in the Second Half of the 19th and Early 20th Centuries. Nauka. (In Russian).

Report on the revision of the Turkestan region, carried out at the Imperial command of Senator Hoffmeister Count K.K. Palen. People's Courts of Turkestan Territory. (1909). n. p. (In Russian).

Russian State Historical Archive. (1871). F. 1405. In. 69. C. 7108 - a. (In Russian).

Russian State Historical Archive. (1897). F. 1291. In. 84. № 18-1897. (In Russian).

Russian State Historical Archive. (1898). F. 565. In. 7. C. 29084. (In Russian).

Russian State Historical Archive. (1904). F. 1587. In. 1. C. 1. (In Russian).

Russian State Historical Archive. (1910). F. 1396. In. 1. C. 441. (In Russian).

Russian State Historical Archive. (1911). F. 1405. In. 532. C. 2. (In Russian).

Russian State Historical Archive. (1913). F. 1405. In. 532. C. 491. (In Russian).

Saliev, A. L. (2013a). On attempts by the Tsarist authorities to bring the judicial procedure of the nomadic population of Turkestan closer to Russian courts and legislation (based on archival, legal and other materials). Bulletin of the Kyrgyz-Russian Slavic University, 13(12), 77-80. (In Russian).

Saliev, A. L. (2013b). The Tsarist Power and the People's Courts of the Nomadic Population of Turkestan: Problems of Relationship (on archival, legal and other materials). Bulletin of the Kyrgyz-Russian Slavic University, 13(6), 41-43. (In Russian).

Terentiev, R. V. (2001). Government bills to reform local justice in Russia in the late 19th and early $20^{\text {th }}$ centuries. Scientific Notes of the V.B. Bobkov St. Petersburg Branch of the Russian Customs Academy, 4, 140-146. (In Russian).

Tukhtametov, F. T. (1999). The Legal Status of Turkestan in the Russian Empire: (Second Half of the 19th Century). Bashkir State University. (In Russian).

Valiev, R. G. (2020). Legal Institutionalization and Legal Institutions: Conceptual Model. Lex Russica, 4, 103-116. https://doi.org/10.17803/1729-5920.2020.161.4.103-116 (In Russian).

Vasiliev, D. V. (2014). The organisation of administration in Russian Turkestan according to the draft Regulations of the 1870s. The online journal "Naukovedenie", 5, 1-23. (In Russian).

Vasiliev, D. V. (2018). A classic example of Orientalism. K. K. Palen's Memoirs as a High Official's View of Russia's Mission in the Turkestan Region. Bulletin of the Orenburg State Pedagogical University, 28, 87-100. https://doi.org/10.32516/2303-9922.2018.28.8 (In Russian).

Vasilyev, D. V., \& Lubichankovsky, S. V. (2018). Administrative Acculturation of the Indigenous Population of Turkestan Province in the Russian Legislation of 1865-1866. Bulletin of Volgograd State University. Series 4: History. Regional Studies. International relations., 6, 61-75.

https://doi.org/10.15688/jvolsu4.2018.6.4 (In Russian). 
Verniaev, I. I. (2018). The Local Court Reform of 1912. In the Imperial Dimension: How to Build Common Institutions in a Multi-Stakeholder Society. Contemporary Russian history, 8(4). https://doi.org/10.21638/11701/spbu24.2018.412 (In Russian).

Zakharov, V. V. (2010). Neoinstitutionalism in Historical and Legal Studies: Towards the Problem of Expanding the Methodological Instrumentation of the Domestic History of State and Law. Scientific notes. Electronic scientific journal of Kursk State University, 3, 36-44. (In Russian).

Zakharova, L. G. (1992). Autocracy and Reforms in Russia. 1861-1874. (To a question on the choice of development). In The Great Reforms in Russia, 1855-1874 (pp. 24-43). MSU Press. (In Russian). 